\title{
Treatment of a Child with Nocturnal Panic Attacks
}

\author{
Onur Burak Dursun¹, Semiha Arslan ${ }^{1}$, Hüseyin Tan², Ömer Özden²
}

ÖZET:

Uykuda panik atakları olan bir çocuk ve tedavi süreci

Uykuda panik atak, uykudan aniden uyanma ve bunu takip eden klasik panik atak bulgularılla karakterizedir. Yetişkin panik bozukluk olgularının neredeyse yarısında görülebilen bu durumun çocuklarda görülmesi ve tedavisi konusunda ise çok az șey bilinmektedir. Bu yazıda çocuk hastalıkları servisinde uykuda geçirdig̃i nöbetler nedeniyle yatarak izlemi yapilırken çocuk ergen ruh sag̃lıg̃ı ve hastalıkları konsültasyonu istenilen; panik bozukluk tanısı konulduktan sonra sertralin ile bulguları tamamen düzelen 12 yașında bir kız çocug̃unun takip ve tedavi süreci sunulmuștur. Uykuda görülen nöbetlere çocukluk çag̃ında sıkça rastlanmakta; bu nöbetler genellikle epilepsi nöbetleri olarak tanımlanıp antiepileptiklerle tedavi edilmeye çalıșılmaktadır. Ancak bu nöbetlerin önemli bir kısmının gerçekte psikojenik kökenli nöbetler oldug̃u bilinmektedir. Gece panik atakları psikojenik kaynaklı nöbetlerin en önemli nedenlerindendir ve tekrarlayıı gece nöbetlerinin aуıгıс tanısında göz önünde bulundurulmalıdır.

Anahtar sözcükler: panik atak, uyku, çocuk, sertralin, tedavi

Journal of Mood Disorders 2014;4(3):133-5

\section{ABSTRACT:}

Treatment of a child with nocturnal panic attacks

Nocturnal panic attack is characterized by sudden awakening from sleep followed by the classical symptoms of panic disorder. Although it occurs nearly in half of adult panic disorder cases, little is known about occurrence and treatment in childhood. In this paper, we present a 12 years old girl, hospitalized in the paediatric inpatient unit for her nocturnal seizures; consulted to child and adolescent psychiatry department during management; diagnosed as panic disorder and recovered with sertraline. Nocturnal panic attack is one of the main causes of nonepileptic seizures that would benefit from psychiatric treatment options and has to be considered in differential diagnosis of nocturnal paroxysmal events.

Key words: panic attack, nocturnal, child, treatment, sertraline

\section{Journal of Mood Disorders 2014;4(3):133-5}

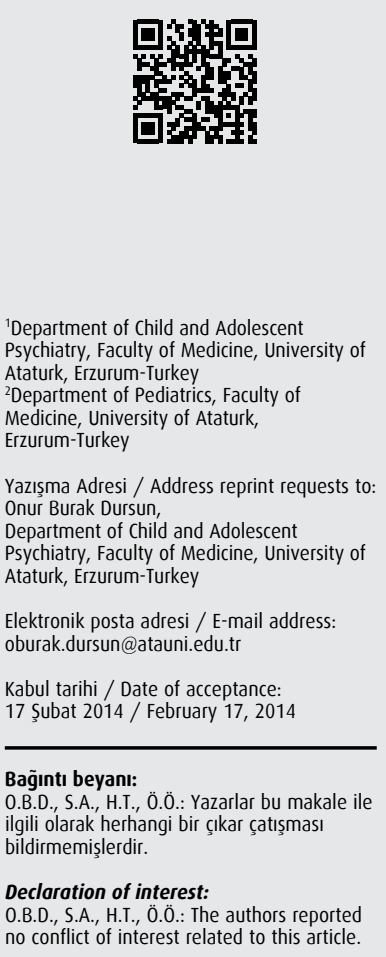

\section{INTRODUCTION}

Paroxysmal night events are prevalent health problems in the general childhood population (1). Although many of these events are thought to have neurologic origins and thus diagnosed and treated as epileptic seizures many studies have shown that nearly one third of them might be misdiagnosed and essentially associated with psychiatric conditions (2).

Nocturnal panic attack (NP) is one of the possible causes of non-epileptic seizures. NP is characterized by an abrupt awakening from sleep in a panic state with a severe choking sensation which is coincided with physical symptoms of a regular panic attack such as palpitation, sweating, shortness of breath (3).Although approximately
$50 \%$ of all adult patients with panic disorder have nocturnal panic attacks there is no systematic data on pharmacological treatment options (3).There is no data on clinical features and pharmacological management of childhood onset NP.

In this case report, we present a 12 years old girl who had nocturnal panic attacks and become asymptomatic with sertraline use.

\section{CASE}

The patient was a 12 years old girl who was first brought to the paediatric outpatient department of Atatürk University by her biologic mother. Her major complaint was awakening seizures during sleep, which 
was first started 2 years ago without any prominent triggering event. The seizures occurred nearly every night, 1-2 hours after she fell asleep. She was experiencing an intense fear accompanied by flashing, sweating, palpitation, shortness of breath, chest pressure, nausea, and heating but not any motor features were witnessed. The duration was 5-10 minutes, she was fully awake and aware of surrounding.The seizures were occurring once a night but she was having difficulty on returning to sleep after that. Firstly, her family had admitted to the state hospitals and several antiepileptic drugs were prescribed with the diagnosis of epilepsy, however she did not benefit from any of those treatments. Then, she admitted to paediatric outpatient department of Ataturk University and hospitalized for exact diagnosis and treatment. During the inpatient management of her, the physical examination, blood pressure and laboratory tests, including complete blood count, thyroid function tests, and blood glucose levels were within normal range. The echocardiographic findings, brain MRI with 1-mm slides, and background activity in EEG during sleep were also registered as normal. On the second week of hospitalization, child and adolescent psychiatric consultation was conducted for a better differential diagnosis. In the detailed psychiatric evaluation, less severe and less frequent day-time attacks with similar symptoms were described. She had a clear anticipatory anxiety and avoidance of sleep. Her family and personal history was uneventful with respect to psychiatric disorders, in particular to sleep disorders. She also had a normal developmental history and an average IQ level. She was told to be as a 'shy and overanxious' girl by her mother; but her family, school and peer functioning were reported to be well. We applied Kiddie Schedule for Affective Disorders and Schizophrenia-Present and Lifetime version (K-SADS-PL). She fulfilled the criteria for Panic Disorder and also had a sub-threshold generalized anxiety disorder. The patient was diagnosed as panic disorder and sertraline was prescribed as 50mg per day. She tolerated the medicine well. We used the interviewer administered nocturnal panic screen to assess the efficacy of treatment; the initial score was 24 and it was interpreted as very high (3). At the end of the third week of treatment, her panic attacks and anticipatory anxiety were completely recovered. The panic screen score also dramatically decreased to 6 .

\section{DISCUSSION}

To our knowledge, this is the first presentation of clinical features and treatment of nocturnal panic attacks in a child. Although the prevalence of panic disorder is around $0.5-5 \%$ in child and adolescent population, little is known about nocturnal panic attacks in this population and the existing data derives from adult literature (4). NP is characterized by sleep time attacks that generally occur in stage II-III of Non-Rem sleep, around 3 hours after sleep. Only night time attacks predominance is rare, most of the NP sufferers also have day-time attacks. As a regular panic attack the seizures goes by arousal symptoms such as tachycardia, sweating, shortness of breath, chest pressure, choking sensations, dizziness or lightheadedness, depersonalization or derealisation, stomach discomfort, andfearsofdyingorgoingcrazyaccompanying an intense fear or apprehension. Motor component is not common in NP. The patient awakes from sleep with an intense sense of panic and the arousal symptoms occur soon after. Patients with NP attacks are fully awake during seizure and can easily recall the events. It takes nearly 2-8 minutes and the avoidance which is one of the main characteristic of panic disorder shows itself as fear of sleep in NP $(1,3)$. Our patient had almost all of the NP symptoms mentioned above.

There is a wide differential diagnosis for sleep time seizures in childhood. Most common reasons of paroxysmal events during sleep are primary parasomnias, epilepsy and non-epileptic events associated with psychiatric conditions (1). Parasomnias are repetitive unusual behaviours or strange experiences that occur related to sleep. They are very common in childhood reaching a prevalence of $80 \%$. Over 15 primary parasomnias were described by the American Academy of Sleep Medicine with different clinical manifestations. Among the parasomnias night terror (NT) have the closest symptomatology to our patient's with the occurrence in 1-2 hours after sleep, the autonomic and emotional symptom dominance, absence of EEG anomalies. But an NT episode generally lasts for 30 minutes; the child is not awake, unaware of event and cannot remember the events. The onset is generally in 1-3 years of age, and avoidance of sleep is not common (5). Epileptic seizures, especially with frontal lobe onset, often/usually occur during sleep. But the clinical features of the nocturnal 
panic attack cases have many differences from a regular epileptic seizure either. First of all, although it is not crucial for diagnoses, there are often specific EEG findings which support the epilepsy diagnosis. Stereotyped motor features are more prominent and the duration is generally 1-2 minutes. The episodes may occur in any time of sleep and maybe more than once a night. The patients are more likely to be unaware of events and verbal interaction can rarely be achieved (6).

The literature data on pharmacological treatment of juvenile panic disorder is very limited, there is a couple of studies showing the positive effects of fluoxetine, sertraline and paroxetine in childhood panic disorder, open controlled trials are available rather than randomized controlled trials (4). Although it has been shown that SSRIs and SNRIs are clearly beneficial and well-tolerated, no medications have been approved by the United States Food and Drug Administration (FDA) for treatment of anxiety in children and adolescents other than Obsessive compulsive disorder (OCD) (7). SSRI's are extensively used as off-label in all anxiety disorders in children and adolescents for the treatment of anxiety disorders (7). Although SSRIs are the first-line medication in adult panic disorder there is also a lack of systematic data on the medical treatment of NP even in adults (3). Sertraline has shown to be beneficial for panic disorder in adults and nearly all of the childhood anxiety disorders (7-9). It was also approved by the FDA for treatment of OCD in children

\section{References:}

1. Vendrame M, Kothare SV. Epileptic and Nonepileptic Paroxysmal Events Out of Sleep in Children. Journal of Clinical Neurophysiology. 2011;28:111.

2. Alper K. Nonepileptic seizures. Neurol Clin. 1994;12:153-73.

3. Craske MG, Tsao JCI. Assessment and treatment of nocturna panic attacks. Sleep Medicine Reviews. 2005;9:173-84.

4. Diler RS. Panic disorder in children and adolescents. Yonsei Med J. 2003;44:174-9.

5. Mason TBA, Pack AI. Sleep terrors in childhood. Journal of Pediatrics. 2005;147:388-91.

6. Provini F, Plazzi G, Lugaresi E. From nocturnal paroxysmal dystonia to nocturnal frontal lobe epilepsy. Clinical Neurophysiology. 2000;111:2-8.

7. Kodish I, Rockhill C, Varley C. Pharmacotherapy for anxiety disorders in children and adolescents. Dialogues Clin Neurosci. 2011;13:439-52. and adolescents (9). In our case, sertraline was tolerated well and provided a full recovery of panic attacks and anticipatory anxiety. To our knowledge, this is the first published data on the treatment of NP in children and adolescents.

Multidisciplinary approach in nocturnal paroxysmal occurrences via the collaboration of paediatricians with child and adolescent psychiatrists is emphasized in the literature (10). Many patients with non-epileptic seizures associated with psychiatric conditions are more likely to seek medical attention, and this group of patients constitutes a larger proportion of the workload of neurologists, general physicians and emergency physicians (11). Leis et al. have found that $69 \%$ of the patients with seizures associated with psychiatric conditions were treated pharmacologically with antiepileptic drugs, up to 360 months of treatment durations (12). The physicians dealing with epilepsy should keep in mind that the seizures of approximately one third of the patients referred for refractory epilepsy are associated with psychiatric conditions (2).

In conclusion, nocturnal panic attack is one of the causes of paroxysmal night events during sleep and has to be considered in differential diagnosis of epilepsy and parasomnias even in children. A multidisciplinary approach and careful psychiatric evaluation is the best way of discriminating NP and sertraline may be an effective and safe alternative in the treatment.

8. Walkup JT, Albano AM, Piacentini J, Birmaher B, Compton SN, Sherrill JT, et al. Cognitive Behavioral Therapy, Sertraline, or a Combination in Childhood Anxiety. New England Journal of Medicine. 2008;359:2753-66.

9. United States Department of Health and Human Services. Drug safety. [cited 10/01/2014]; Available from: http://www.fda.gov/ drugs/drugsafety/informationbydrugclass/ucm096273.

10. Iriarte J, Parra J, Urrestarazu E, Kuyk J. Controversies in the diagnosis and management of psychogenic pseudoseizures. Epilepsy \& Behavior. 2003;4:354-9.

11. Goodyer IM, Mitchell C. Somatic emotional disorders in childhood and adolescence. Journal of psychosomatic research. 1989;33:6818 .

12. Leis AA, Ross MA, Summers AK. Psychogenic seizures: ictal characteristics and diagnostic pitfalls. Neurology. 1992;42:95-9. 